の良いものとし, 且つ, 吸排気流路形状の改善を行なっ てシリンダ内への流入空気の増加を図っている. 更に, ピストン冠上面の形状は最適の燃焼室形状を形成してお り, 且つ, 燃料噴射弁は数多くの実績により噴口の径, 数, 角度に最適のものを選定しているため, 燃焼が非常 に良好で，そのため, シリンダ直径の割合にはかなり低 質油まで使用が可能であり，また，排気温度す低く，燃 料消費率む少ない。

2.4 長期無解放運転が可能である 前述の燃焼 を良好にするととと，排気温度を下げることにより燃焼 室周辺のカーボン堆積を極度に少なくした. 更汇，ピス トン冷却を行なってピストン冠及びピストンリングの温 度を下げたので，適正なアルカリ価を持たせた高級潤滑 油の使用之相まって，ピストンの污れを少なくした。ま た、シリンダライナは硬質クロームメッキを施してある ので, 摩耗が非常に少ないのはむち万ん,メッキライナ としゅう動するピストンリングの摩耗も少ないので，ピ ストンリングあ長期間の使用に耐えられる。また，ピス トンピンは浮動式としてある上にピストン冷却油を通す ことによりメタルの温度も下がり，ピストンピン及びブ ラスの寿命も長くなっている. 更にクランクブラスは薄 肉 4 層メタルを採用して, ホワイトの割れ、はく離, 焼 付の心粑をなくしているので， 2 年間の無解放運転が可 能であり全く問題がない.

2.5 その他伝導歯車はへリカル歯車を採用し, 中間㐘車軸は強固に保持し, 歯面には積極的に注油を施 し，精密な雬車工作之相まってかみ合いが円滑で騒音が少 なく歯面のピッチングが皆無である．主機の前後進切換 えはカム軸の後前への移動によって行なうが, 力ム軸駆 動の動力伝達は内歯々車とビニオン歯車とのか子合いス ライド方式にしてあるので, 回転伝導が円滑であり軸の 後前移動屯滑らか汇行なえる.

スラスト軸はクランク軸と一体になって抢り，スラス
卜軸受は機関台板に内蔵されているため，すえ付時の芯 出しが容易であり, 軸受の保持が強固で変形が少なく, スラスト負荷能力む大きく, 楖久性に優れ, 機関全長む 短くできている.

\section{I.11 三菱重工業(株)*}

$$
\text { 山本 清昭** }
$$

\section{1. まえがき}

三菱重工業(株)では, 従来から一般船舶用主機, 漁 船用主機及び舶用発電機用補機など各種用途に適した高 速ディーゼル機関を製作し好評を得ている。

近年, 船舶の高速化, 運航経費の節減, 機関スペース の縮少化,メインテナンスの容易化などューザニーズは ますます多様化してきている．乙れらの要求に応じて， 当社として, $400 \mathrm{PS} \sim 1,000 \mathrm{PS}$ の範囲に扔いて, 常用 回転数が $900 \mathrm{rpm}$ 付近で使用される重作業船を主たる用

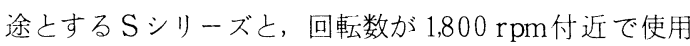
される発電機用及び高速漁船, 高速艇の主機を主たる用 途としたSAシリーズをそれぞれ完成し，51 年より逐次 発売を開始している．以下この二つのシリーズについて 概要を紹介する.

$$
\text { 2. Sシリーズについて }
$$

2.1 開発のねらい 本シリーズの開発の主なねら いは，底引漁船や，かつ㧍，まぐろ漁船のごとく，重負 荷でしかも比較的低回転数で使用されるなどの厳しい条 件に適した，耐久性之信頼性を特に付与するとと，低然 費であり，分解整備を容易にし総合的な経済性をたかめ ることを考虑したあのである。表 1.11 .1 亿 S シリーズの 主要目, 図 1.11.1亿4シリンダ機関 $4 \mathrm{SAC}-1$ 形の機関 断面図を示す。

\begin{tabular}{|c|c|c|c|}
\hline 種 & $4 \mathrm{SAC}-1$ & $6 \mathrm{SAC}-1$ & $6 \mathrm{SGAC}-1$ \\
\hline 形 & \multicolumn{3}{|c|}{ 四サイクル，水冷，排気ターボ付，インタークーラ付 } \\
\hline シ & 4 & 6 & 6 \\
\hline シリンダ径 $\times$ 行 程 & \multicolumn{2}{|c|}{$200 \times 240$} & $220 \times 240$ \\
\hline 程 & 30.16 & 45.24 & 54.74 \\
\hline 燃 & \multicolumn{3}{|c|}{ 直接噴射式 } \\
\hline IE & \multicolumn{2}{|c|}{13} & 12.5 \\
\hline 連 続 定 格 出 & $500 / 1,000$ & $750 / 900$ & $900 / 900$ \\
\hline 燃料消費摔（クラッ千付） g/PS /h & 165 & 165 & 160 \\
\hline 寸法（クラッチ付）（長×幅×高） & $3,172 \times 1,447 \times 1,997$ & $4,065 \times 1,514 \times 2,137$ & $4,125 \times 1,598 \times 2,160$ \\
\hline 乾燥重量（クラッチ付） & 6,500 & 8,950 & 9,300 \\
\hline 使 & \multicolumn{3}{|c|}{ A重油 (JIS) } \\
\hline 始 & \multirow{2}{*}{\multicolumn{3}{|c|}{$\begin{array}{l}\text { 空気始動 } \\
\text { 海水直接泠却 }\end{array}$}} \\
\hline 冷 & & & \\
\hline 過 & \multicolumn{2}{|c|}{ 三菱STC $80 \mathrm{~A}$ 形 } & 三菱STC $80 \mathrm{~B}$ 形 \\
\hline 逆 & \multicolumn{3}{|c|}{ 油圧多板式 } \\
\hline
\end{tabular}

表 1.11.1 Sシリーズ機関主要目 (舶用主機)

* 原稿受付 昭和 53 年 11 月 27 日

**正会員 三菱重工業（株）発動機事業部（相模原市田名 3000 番地) 


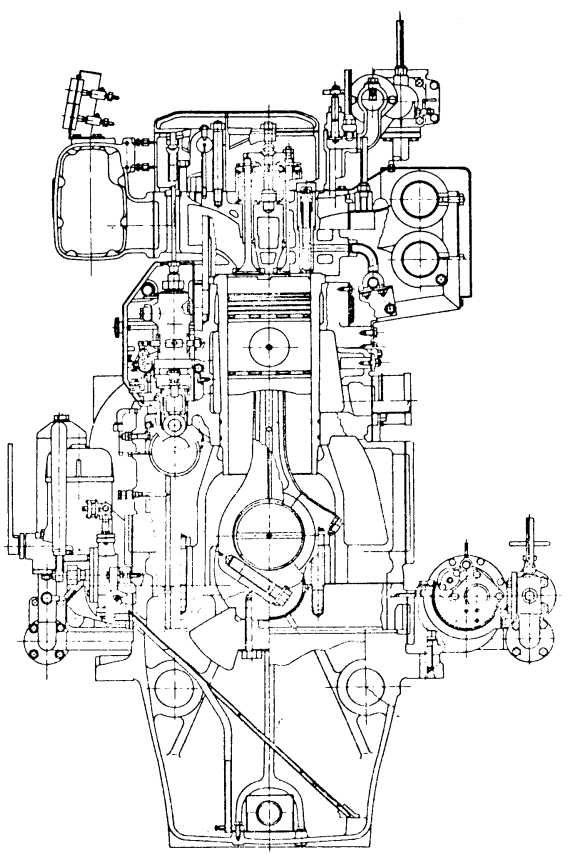

図 1.11.14 SAC-1 形機関断面図

\section{2 主な特徴}

（1）高い信頼性, 耐久性 シリンダヘッドは熱負荷 低減を䄈らって，2段冷却方式及び燃燒研究により，燃 焼室壁温は $243{ }^{\circ} \mathrm{C}$ と低いため，き裂に対す万問題はなく， 吸排気弁は弁, 弁座にステライトを盛金し, バルブロー テータを使用することにより，寿命が大幅に延びる。ま たピストンはトップリング溝の温度を $160{ }^{\circ} \mathrm{C}$ 以下に保つ ため冷却蛇管入りのアルミ合金製とした，乙の結果，ま ぐろ漁船で 2 年間 (12,000 時間) の分解調査 でライナ、リング，弁まわりの摩耗はほ之 んどなく耐久性について十分満足する成績を 得ている.

（2）低燃料消費率当社で開発した高効 率の過給機 STC 80 形を採用し, 充てん効率 向上のために四弁方式の採用, 吸気スワール 之燃料噴射特性の最適マッチングにより，定 格時の燃費は $160 \mathrm{~g} / \mathrm{PS} ・ \mathrm{~h}$ 以下 (クラッチ減 速機付), 排気濃度はボッシュ濃度で 0.2 以 下と好成績を得ている。

3）船内整備の容易化狭い船内での分 解整備を容易にするととを最重視して，クラ ンク軸の支持はいわゆる台板形式とし，シリ ンダ及びクランク室の締付は支柱ボルトを使 用せず，締付けを内締めとする一体構造とし た、また,クランクピンメタル, 主軸受メタ ルの点検は側空より点検できる. また，力ム 軸は分割形とするなどすべての分解が船内で 可能である.
4） 4 シリンダ機関の振動対策 一般に 4 シリンダ 機関は 6 シリンダ機関に比べて上下振動の点で不利な面 が大きく，ての級ではあまり実用化されていない．本シ リーズの $4 \mathrm{SAC}-1$ 形では，二次の上下慣性力を打ち消 すような一対のカウンターウエイトをあったバランサー をクランク室内に装着している。その結果， 6 シリンダ 機関なみの振動となり，全長，重量，メンテナンスコス トの点で優れた特徴をもつ機関となった。

\section{SAシリーズについて}

3.1 開発のねらい 本シリーズの開発のねらい は, 常用回転数が $1,200 \sim 1,800 \mathrm{rpm}$ の広範囲の発電用を 中心亡し, 高速艇,及び高速漁船の主機用に小形, 軽量, 高出力であるとと，低燃費であると之もに欧米の高速機 関に対して耐久性，信頼性の点でまさること，従来やや あすると高速機の欠点とされている船内での整備性を容 易化すること，また，舶用加陸用発電機，建設機械 用として広い用途に対しはん用性をあたせることであ る. 表 1.11 .2 亿 SAシリーズの主な要目, 図 1.11.2 亿 S 12 ATKの機関断面図を示す。

\section{2 主な特徴}

（1）軽量, 高出力 シリンダクランクケースをはじ め主要鋳鉄部品は，効果的なりブを配置するととにより 極力軽量化を計りながら, 一方では出力率 $P_{\mathrm{me}} \cdot C_{\mathrm{m}}=164$ $\mathrm{kg} / \mathrm{cm}^{2} \cdot \mathrm{m} / \mathrm{s}$ までの高い出力での耐久テストで十分強 度面の信頼性を確認している. このため, 馬力当りの重 量は $3 \mathrm{~kg} / \mathrm{PS}$ 台の目標を満足した。

（2）低燃料消費率四弁方式の採用，最適なスワール を得るための 2 段式スワールポートの採用, 燃料噴射系に ついてカムプロフィルの改良により高圧噴射化を行なうと

表 1.11.2 SAシリーズ機関主要目

\begin{tabular}{|c|c|c|}
\hline 種 & S6ATK & S12ATK \\
\hline 形 式 & \multicolumn{2}{|c|}{$\begin{array}{l}\text { 四サイクル, 水冷, 排気ターボ付, インターク } \\
\text { ーラ付 }\end{array}$} \\
\hline \begin{tabular}{lllll|} 
シ & リ & ン & ダ & 数 \\
\end{tabular} & 6 & $12 \mathrm{~V}$ \\
\hline $\begin{array}{c}\text { シリンダ径 } \times \text { 行程 } \\
\mathrm{mm}\end{array}$ & \multicolumn{2}{|c|}{$145 \times 160$} \\
\hline $\begin{array}{cccc}\text { 総 } & \text { 行 } \begin{array}{c}\text { 程 } \\
\end{array} & \text { 容 } & \text { 積 } \\
& & & \end{array}$ & 15.85 & 31.70 \\
\hline 焼 方 & \multicolumn{2}{|c|}{ 直接噴射式 } \\
\hline 縮 & \multicolumn{2}{|c|}{14.5} \\
\hline $\begin{array}{c}\text { 連続定格出力主機 } \\
\mathrm{PS} / \mathrm{rpm}\end{array}$ & $415 / 2,000$ & $830 / 2,000$ \\
\hline $\begin{array}{c}\text { 連続定格出力補機 } \\
\mathrm{PS} / \mathrm{rpm}\end{array}$ & $400 / 1,800$ & $800 / 1,800$ \\
\hline $\begin{array}{c}\text { 最低燃料消費率 } \\
\mathrm{g} / \mathrm{PS} / \mathrm{h}\end{array}$ & \multicolumn{2}{|c|}{155} \\
\hline $\begin{array}{c}\text { 本体寸法 (長×幅×高) } \\
\mathrm{mm}\end{array}$ & $1,610 \times 908 \times 1,304$ & $1,915 \times 1,290 \times 1,543$ \\
\hline 乾 燥 $\mathrm{kg}$ 重 量 & 1,630 & 2,930 \\
\hline 燃 & \multicolumn{2}{|c|}{ A 重油（JIS）または軽油（JIS 2 号） } \\
\hline 動 方 & \multicolumn{2}{|c|}{ 電気始動標準（空気始動可能） } \\
\hline 却方 & \multicolumn{2}{|c|}{ 清水間接冷却 } \\
\hline 給 & \multicolumn{2}{|c|}{ 三菱シュウィッツァ式 } \\
\hline
\end{tabular}




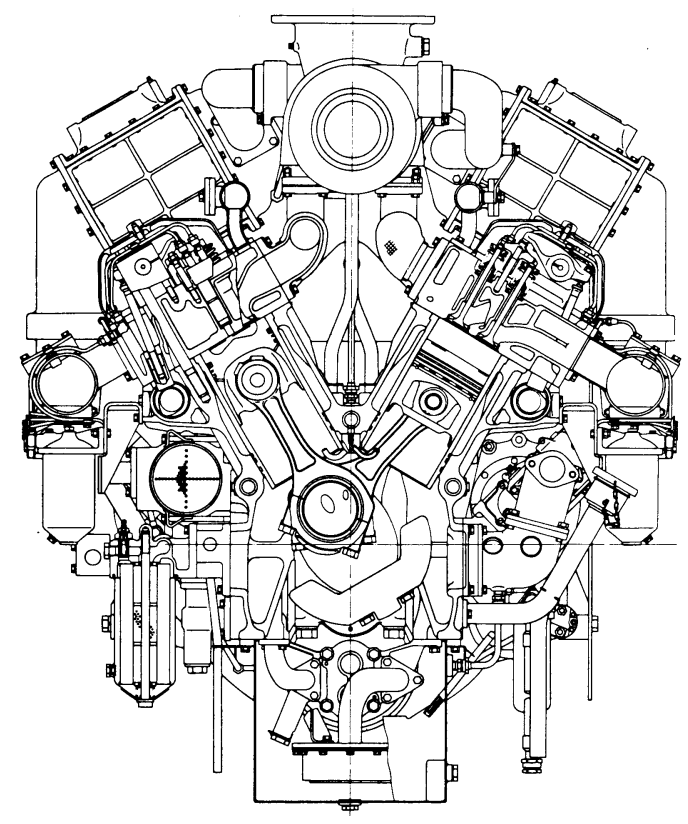

図1.11.2 S 12ATK機関断面図

とむに，三菱シュビッツア形の高効率の過給機との適正な マッチングにより最低燃料消費率は $155 \mathrm{~g} / \mathrm{PS}$ 得ている。

（3）はん用性 舶用, 産業用, 建設機械用之広い分 野の二ーズに応じるため, クランク軸の前端より $100 \%$ 出力の取出しが可能であり, 始動方式は電気式のほかに 空気始動方式屯可能である，そのほか，長時間連続運転 用として大容量のオイルパンを用意し，冷却方式につい ても外部からの冷却水を利用する間接冷却方式のほかに ラジェータ冷却方式も可能である。なお，側空を設けて ありピストンの抜き出しが船内で可能である.

\section{4. むすび}

以上, $\mathrm{S}$ 及び $\mathrm{SA}$ 二つのシリーズについて概要を紹 介したが，各方面の使用条件に適応した機関としてそれ ぞれの分野で現在活躍しており, 開発のねらいは一応成 果を得たと考えている.

今後は,ユーザに使って喜ばれる，よりいっそう信頼 性経済性の高い製品の開発に，また，燃料消費率の向上 など基礎研究に努力を続けたい.

\subsection{2 池貝鉄工(株)}

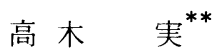

\section{1.はじめに}

当社は 1896 年に我が国で最初に石油機関を製作した

* 原稿受付 昭和 53 年 10 月 25 日

**正会員 池貝鉄工 (株) 神明工場 (川崎市幸区神明町 1-80)

Journal of the M.E.S.J., Vol.14, No.2
会社であるが, 1960 年西独ダイムラ・ベンツ社とMB 820/836 形高速ディーゼル機関の技術契約を結んで以来, 一貫して高速ディーゼル機関の生産を行ない現在に至っ ている.

\section{652 形高速ディーゼル機関}

従来から生産してきたMB820形機関の最大出力は 1,360 PSであるが更に高出力の高速ディーゼル機関の需要が 将来見込まれることから本機関の追加契約をMTU社之 結び，1974年より生産を開始した。なお，MTU社はダ イムラ・ベンツ社の大形高速ディーゼル部門と MAN 社 のガスタービン部門を統合して創立された会社である。

表 1.12.1 亿本機関の主要目表を, 図 1.12.1 亿内部構 造図を示す，本機関については既に文献 1 亿照会済であ るので，ここでは構造及び性能上の特長について簡単に 記す。

機関本体はクランクケースとシリンダブロックの一体 構造で材質は鋳鉄または軽合金製で本体を上下に貫通す るタイロッドによって剛性を高めている.

シリンダヘッドは鋳鉄製で各々 2 個の吸排気孔を有し， 中央に耐熱鋼製の予燃焼室が取りつけられ，その先端に は 6 個の長孔噴孔を有するC 級超合金鋼製の口金が電子 ビーム溶接されている.

ピストンは油泠却組立形ピストンで軽合金鍛造製の胴 部に耐熱鋼製の冠部が燃焼室側から 6 本のボルトで取り

表 1.12.1 機関主要目

\begin{tabular}{|c|c|c|}
\hline 式 & \multicolumn{2}{|c|}{$\begin{array}{l}\text { 水冷 } 4 \text { サイクル空気冷却器付 } \\
\text { 排気タービン過給ディーゼル機関 }\end{array}$} \\
\hline & $12 \mathrm{~V} 652$ & $16 V 652$ \\
\hline リンン ダ & 12 & 16 \\
\hline $\begin{array}{c}\text { 角 } \\
\mathrm{deg}\end{array}$ & \multicolumn{2}{|c|}{45} \\
\hline $\begin{array}{c}\text { シリンダ数×ストローク } \\
\mathrm{mm}\end{array}$ & \multicolumn{2}{|c|}{$190 \times 230$} \\
\hline 1 シリンダ当り排気容積 & \multicolumn{2}{|c|}{6.52} \\
\hline $\begin{array}{ccc}\text { 総 排 } \begin{array}{c}\text { 気 } \\
\end{array} \text { 容 積 } \\
\end{array}$ & 78.2 & 104.3 \\
\hline 縮 & \multirow{2}{*}{\multicolumn{2}{|c|}{$\begin{array}{c}15.25 \\
\text { 予燃焼室 }\end{array}$}} \\
\hline 燃 焼 室 & & \\
\hline \multirow{3}{*}{$\begin{array}{c}\text { 最大出力 / 回転数 } \\
\mathrm{PS} / \mathrm{rpm} \\
\text { 同上時平均有効压力 } \\
\mathrm{kg} / \mathrm{cm}^{2} \\
\text { 同上時平均ピストン速度 } \\
\mathrm{m} / \mathrm{s}\end{array}$} & $2,060 / 1,485$ & $2,750 / 1,485$ \\
\hline & 15.97 & 15.98 \\
\hline & \multicolumn{2}{|c|}{11.39} \\
\hline $\begin{array}{c}1 \text { シリンダ当り出力 } \\
\mathrm{PS}\end{array}$ & 171.7 & 171.9 \\
\hline $\begin{array}{c}\text { 乾燥 重量（軽合金架構） } \\
\text { kg }\end{array}$ & $5,560(4,510)$ & $7,380(6,240)$ \\
\hline 馬力当り重量 & $2.70(2.19)$ & $2.68(2.27)$ \\
\hline 機関 全長 & 3,500 & 4,020 \\
\hline 全 高 & 2,230 & 2,270 \\
\hline 全 幅 & 1,750 & 1,800 \\
\hline 向 & \multicolumn{2}{|c|}{ 出力側よりみて右または左 } \\
\hline 起 動 方 式 & 空気または電気 & 空気 \\
\hline $\begin{array}{c}\text { アイドリング回転数 } \\
\mathrm{rpm}\end{array}$ & \\
\hline
\end{tabular}

February, 1979 